\title{
AZ E-KÖZIGAZGATÁS ELMÉLETÉNEK MEGALAPOZÁSA
}

A közigazgatás rapid átalakulása, újraszervezése súlyos kényszerek és elvárások mentén történik napjainkban. A közigazgatás, ezen keresztül az állam teljesítóképessége szempontjából sem mindegy, hogy ez az átalakulás tudományos háttér, módszertan és eszköztár segítségével, vagy anélkül, ad hoc módon történik. Az e-közigazgatásra mint új tudományterületre nagy feladat hárul. Kapaszkodót kell adni az átalakuláshoz, ki kell jelölni a tudományos diskurzus fóbb fókuszpontjait, a megújítás és a megújulás területeit és módszereit. Így jutunk el a közigazgatás új megközelítéséhez, gondolati térképéhez és bejárási ,itineréhez”. A tanulmány arra tesz kísérletet, hogy axiomatikus megközelítésben mutassa be a közigazgatási modernizáció fő sodrának számító e-közigazgatás tudományának fóbb pilléreit, segédtudományait és azok bejárási irányát. Számba vegye a tudomány diskurzusát, fogalmi hátterét, végül vizsgálja a paradigma-diffúzió új fogalmát és jelenségét a közigazgatásban.

Kulcsszavak: e-közigazgatás, közigazgatási modernizáció, axiomatikus megközelítés, e-közigazgatástudomány

A közigazgatás modernizációs kényszer alatt változik napjainkban. (A változás iránya vita tárgyát képezi.) A kényszer több irányból érkezik: érezzük ,fentről” az Európai Közigazgatási Tér nyomását, ami EU-komform, EU-kompatibilis közigazgatást vár el a tagállamoktól. Nyomást tapasztalunk „lentról”, a társadalom felól is, ahol olyan elvárásokkal találkozunk, mint az elektronikus úton megvalósuló közszolgáltatások követelménye, vagy a „pénzért értéket” elv számonkérése: az állampolgárok joggal várhatják el, hogy adóikért minôségi szolgáltatást kapjanak. Végül számolnunk kell egy belsố nyomással is. A közigazgatás jelen formájában - finanszírozását tekintve is - tarthatatlan. Nem csupán az jelent problémát, hogy fölösleges funkciókat, hivatalokat (önkormányzatokat) tart fenn az állam, hanem az is, hogy az indokoltnak tünő funkciókat ellátó intézmények múködése is redundáns és pazarló. A probléma pedig - gazdasági válság övezte környezetünkben - kifejezetten érzékenyíti a mindenkori kormányzatot a közigazgatás „karcsúsítására” vagy „áramvonalasabbá" tételére. A dinamikus szervezeti formák és a hatékonyabb szolgáltatások megteremtése azonban nem a „fúnyíróelv” következetes alkalmazásánál kezdődik. Az említett háromféle nyomás fenekestül fordítja fel a közigazgatást.
Az átalakulás történhet ad hoc módon, vagy a tudomány eszköztárának felhasználásával. Ha ez utóbbit választjuk, akkor a tudomány elôtt nagy feladat áll: ki kell jelölnünk a diskurzus fóbb fókuszpontjait, a megújítás és a megújulás területeit és módszereit. Így jutunk el a közigazgatás új megközelítéséhez, gondolati térképéhez és bejárási ,itineréhez”.

\section{Az átalakulás kényszere, a diskurzus fóbb fókuszpontjai}

Az e-közigazgatás közel egy évtizedes múltja számos tudományos szempontból értékes lenyomatot halmozott fel, amelyek lassan-lassan koherens egésszé állnak össze. A búza közül az ocsu kiválasztása nem egyszerú, hiszen egyre több információ, ismeret, összefüggés áll elôttünk és a sarokpontok rögzítése is eleddig váratott magára és a mindenkori kormányzat sem igényelte a tudományos alapok lerakását.

Ráadásul egy kialakulóban levő új szakterület tudományos diskurzusának produktumait eleinte nehéz is összegyứjteni, a tudományként való intézményesedés folyamata azonban számos forrást bocsát az adott terület rendszerezésére törekvő elméletalkotó rendelkezésére. 
A kiindulási pontot jelentő „kályhát” számomra a szakirodalmi hagyomány biztosította. Tapasztaltam, hogy míg a hazai szakirodalom csupán néhány szerzôt (és leíró jellegú munkát) tud felsorakoztatni, addig a külföldi irodalom már számos szintézist és vitát is számon tart.

$\mathrm{Az}$ írott források feldolgozásának első lépését a szakfolyóiratok számbavétele jelentette. Ortodox e-közigazgatási profilú szakfolyóirat egyeloóre nincs, azonban mind a nyomtatott, mind az elektronikus sajtó jelentôs figyelmet szentel ennek a területnek. Az e-közigazgatással foglalkozó közlemények elsôsorban igazgatásszervezési fórumokon (pl. Localinfo, onkormanyzati.mindentudo. hu), közigazgatási-informatikai szaklapokban (pl. Jegyzó és Közigazgatás), valamint államigazgatási és jogelméleti folyóiratokban (pl. Magyar Közigazgatás) jelennek meg. Az on-line „sajtó” - részben különféle tematikus mellékleteknek (pl. Computerworld, Hwsw, $S g$ ), hírleveleknek (pl. dgOnline - www.dgsociety.org) és gyújtốportáloknak (pl. epractice.eu, magyarorszag. hu, e-kormanyzat.lap.hu, e-onkormanyzat.lap.hu) köszönhetően - már színesebb.

Az egyéb források közül fóként a konferenciák, workshopok nyújtottak jelentős merítési lehetőséget. Magyarországon havonta egy-két nagyobb konferencia foglalkozik az e-közigazgatással összefüggő kérdésekkel, míg az Európai Unió területén szinte folyamatosak az egymást váltó konferenciák. A hazai konferenciák - ritka kivételektől eltekintve - nem lépnek túl a match-making és a lobbizás területén: elsôsorban üzleti célzatúak. Valódi kérdések elvétve kerülnek elő. A hazai workshopok alkalmából azonban számos érdemi szakmai vitakérdés is napirendre kerül. Ilyen szakmai fórumokat rendezett a közelmúltban többek között a Magyary Zoltán E-közigazgatástudományi Egyesület, az E-government Alapítvány, az M-közigazgatási Információs Egyesület, az ITTK, az MTA Filozófiai Kutatóintézete, valamint a Pécsi Tudományegyetem Informatikai és Kommunikációs Jogi Kutatóintézete is. Az utóbbi években tartott jelentôsebb nemzetközi konferenciák (International EGOV conference, eGov Day - DEXA, Hawaii International Conference on System Sciences - HICSS, Strategic Workshops Shaping future EU-NSF collaborations in Information Technologies stb.) napirendjén súrún szerepelt a tudományos kérdések valódi diszkussziója.

A tudományosodás kezdeti fázisát tekintve szükségképpen meg kellett vizsgálni a szakirányú egyetemi képzés, a curriculumok és a doktori programok világát. Az egyetemi képzés területén hazánkban az e-közigazgatási szakismeretek oktatása fellendülóben van. Az igazgatásszervezési alap- és mesterképzés tematikájában kötelezố tárgyként szerepel pl. a Corvinus Egyetem
Közigazgatástudományi Karán, és a közigazgatási és közszolgálati tárgyakat oktató más felsőoktatási intézmények is (a Pécsi Tudományegyetem Közgazdaságtudományi Kara és Jogi Kara, a Debreceni Egyetem Jogi Kara, a Miskolci Egyetemen a Jogi, a Gépészmérnöki és az Informatikai Kar, a Corvinus Egyetem Közgazdaságtudományi Kara, az Eszterházy Károly Főiskolán a gazdasági és a menedzsment szak, a Károly Róbert Főiskola stb.) - legalább ajánlott irodalomként - beillesztik programjaikba az e-közigazgatásról szóló múveket. A tudományt gazdagítják az idôszakosan múködő önképzố egységek, tudományos diákkörök is. Az üzleti szféra gyakorlati tapasztalatai (esetenként a cégek által delegált oktatók személyén keresztül) szintén gyakran beépülnek a curriculumokba. A tudomány így gyakorlati visszajelzést is kap. A képzés legmagasabb fokozatát, a doktori tanulmányokat ugyancsak megérintette már hazánkban is az e-közigazgatás szelleme. Több egyetem (pl. a Pécsi Tudományegyetem és a Corvinus Egyetem) jogi és közigazgatási doktori iskolája vette szárnyai alá e-közigazgatási témákat (vagy azok egyes vetületeit) kutató doktoranduszokat. Kifejezetten e-közigazgatási profilú alap- és mesterképzés ${ }^{1}$, illetve doktori iskola azonban egyelőre még nincs Magyarországon. Külföldön mindhárom szinten találunk jó példákat.

Végül a gyakorlat szóbeli és írásbeli visszajelzései csiszoltak a fóbb irányokon. Az elmélet gyakorlati alkalmazásának visszajelzései szintén alakítják a földtôl néha elszakadó teóriákat. Mind a közigazgatási intézmények (pl. közigazgatási hivatalok) és a pilotprogramokat gesztoráló hivatalok, mind a nagyobb érdekképviseleti szervek (pl. ITOSZ, TOOSZ, MJVSZ stb.) gyakran juttatják kifejezésre a sokszor csak elméleti alapokra támaszkodó szabályozások kritikáját.

$\mathrm{Az}$ így kapott manifesztumokat érdekes volt öszszevetni a finanszírozott kutatási irányokkal, hiszen a pénz mindig fontos szerepet játszik a vizsgálatok és a szakmai diskurzusok tárgyának meghatározásában. Az összevetés azonban nem hozott meglepetést. Az e-közigazgatás tudományának profilját évekre meghatározza, hogy a tudomány mely kérdéseinek kutatását finanszírozzák a nemzeti és nemzetközi szervezetek. Kiemelkedố anyagi forrásokat biztosít a National Science Foundation $(N S F)^{2}$, amely 1950 óta szabja meg az amerikai kutatások irányát jelentős támogatásokkal, valamint az EU több keretprogramja is.

\section{A megújítás tudományterületei és módszerei}

A fenti tárgyalási területek alapján jól látszanak azok a tudományterületek, amelyek szemüvegén keresztül vizsgáltuk eddig az e-közigazgatás egy-egy szegmen- 
sét. A rendszeralkotási igény hiánya azonban a hatást gyakorló interdiszciplínák túlhangsúlyozásához vezetett eddig, amelynek következtében az e-közigazgatást gyakran tekintették informatikai, vagy szervezési kérdésnek, néhol csupán jogi, szabályozási kérdésnek.

Azonban a tudományosodás eredményeként mára tudjuk, hogy e jól csengó és egyre többet sejtetô kifejezés - az e-government, e-governance - mögött egy olyan új, valóban interdiszciplináris területról van szó, amelynek tárgya, módszerei, nyelvezete és elméleti alapjai vannak, bár még igencsak formálódó, cseppfolyós állapotban.

Az e-közigazgatást sokféleképpen lehet megközelíteni. Közigazgatás-tudományi hagyományok alapján vertikális és horizontális megközelítést egyaránt használhatunk. Vertikális megközelítéssel az egyes szakigazgatási területeket és az ott alkalmazható egyedi megoldásokat és módszereket vizsgálhatjuk, horizontális megközelítéssel pedig az egész közigazgatást átható jellemzóket vethetjük vizsgálat alá. Én ez utóbbit választottam, hiszen ez alkalmas arra, hogy az e-közigazgatás elméletét, annak minden területére vonatkozó törvényszerúségeit feltárjuk. Ha pedig törvényszerúségeket látunk, akkor magától értetődően adódik az axiomatikus megközelítés.

Ennek lényege, hogy a feltárt jellemzóket, törvényszerúségeket, törvényeket, megállapításokat (lehetôség szerint axiómákat) egymáshoz illesztve olyan rendszert kapunk, amely alapján az e-közigazgatás múködése és karakterisztikája egyre inkább hézagmentesen leírható.

A tárgy szempontjából releváns megállapítások jelentôs része más tudományterületektôl származik. Ezeket integrálva az e-közigazgatás tudományának áttekintéséhez az alábbi ábrát hívtam segítségül, amely a segédtudományokat és a terület bejárási irányát mutatja. Az 1. ábrán jól látható, hogy az e-közigazgatás alapvetóen három tudományterület, nevezetesen a közigazgatás-tudomány, az informatika, valamint a szervezés- és vezetéstudomány határán jött létre. Mindhárom pillére egyformán stabil és nélkülözhetetlen: bármelyiket elhagyjuk, másik interdiszciplináris területre tévedünk.

1. ábra

\section{Az e-közigazgatás segédtudományai és kialakulásának bejárási iránya}

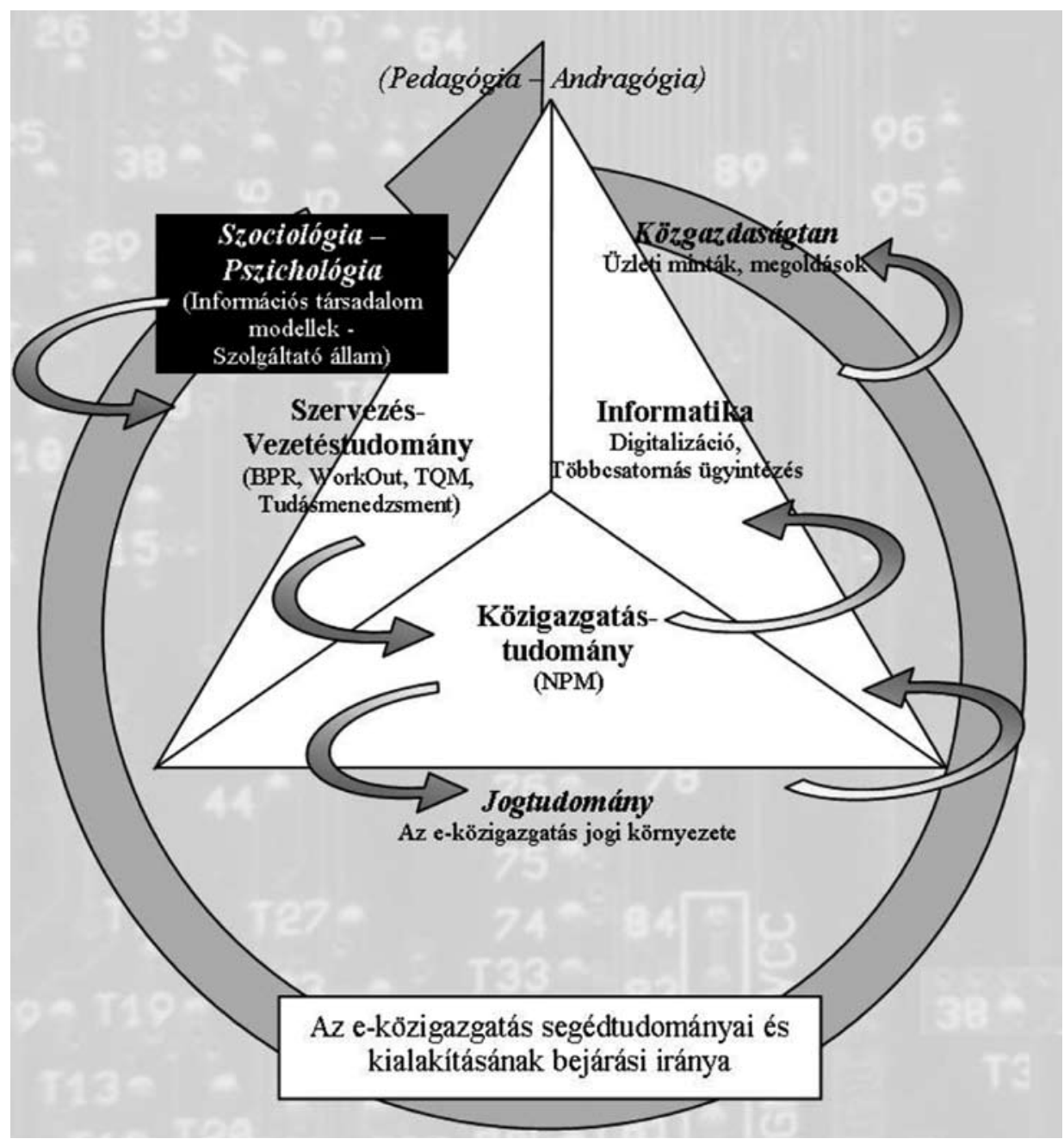

A háromszög körül más és más különböző tudományterületek sorakoznak fel. A közgazdaságtudomány tárházában számos olyan módszer van, amelyek a közigazgatás számára hasznos üzleti modelleket kínálnak (pl. BPR, Workout, ASP megoldások, Reengineering stb.), és ma már minden igazgatási döntéshozónak tudnia kell például azt is, hogy mit jelent a $T C O$ kifejezés. ${ }^{3}$ Figyelembe kell vennünk a szociológia, a pszichológia és szociálpszichológia eredményeit is (kezdve attól, hogy hogyan formálódik a társadalom, mi, hogyan és miért képezi a keresleti oldalt az e-közigazgatáshoz, egészen addig, hogy 
egy on-line elérhetô portálon hol és hogyan kínáljunk szolgáltatásokat, kikre számíthatunk, kiből milyen reakciókat vált ki valamilyen e-ügyintézési forma). Nem feledkezhetünk meg a jogtudományról sem: tudnunk kell, hogy meddig nyújtózkodhatunk. Végül, de korántsem utolsósorban számításba kell vennünk a pedagógia, illetve az andragógia potenciális hozzájárulását is, hiszen az e-közigazgatáshoz (mind a szolgáltatói, mind a felhasználói oldalon) folyamatosan komoly képzési háttérre van szükség.

Érdekes tapasztalat, hogy az így kialakult háromszög és a körülötte elhelyezkedő határterületek bejárásának meghatározott iránya segíti a megértést. Rájöttünk arra, hogy az e-közigazgatás egyes szolgáltatásainak kialakítása olyan ciklust követ, amelyben a tudományterületek egymásra gyakorolt hatásai ismétlődnek. Ezeket a hatásokat és kölcsönhatásokat jelölik az ábrán található nyilak.

Minden interdiszciplináris tudományterület közös sajátossága, hogy a határtudományok képviselôi mindannyian ,értenek hozzá”, így számtalan önjelölt informatikus, ,közigazgatász”, jogász és sok egyszerú vezetố, tanácsadó is az e-kormányzat szakértôjeként lép fel. Az egyéni „látomások” többnyire a felvázolt háromszög egy-egy oldalának túlhangsúlyozásából, esetleg „kívülról történő bekiabálásokból" fakadnak, nem beszélve azoknak a „szakvéleményéroól”, akik a háromszögnek háttal állnak és tagadják az e-kormányzat létezését. Az igazat megvallva, kevesen vannak, akik valóban értik és látják a lényeget. A lényeg a közigazgatás adminisztratív feladatainak minél hatékonyabb és eredményesebb ellátása úgy, hogy a gépezet fenntartói (azok, akik a közterhek viselése révén fizetik a közszolgákat) minél kényelmesebben és gondtalanul tudják ügyeiket intézni. Ezt nevezik „szolgáltató jellegư” közigazgatásnak, ami nem tévesztendő össze a New Public Management piacorientált szemléletú irányzatával, amely az 1980-as években a közigazgatás költséghatékonyságának javítását túzte ki célul, és gyakran érvényesül még ma is. ${ }^{4}$

$\mathrm{Az}$ integrált felfogás nem vette el a létjogosultságát a korábbi szúkebb megközelítéseknek, csupán más dimenzióba helyezte azokat. Például a nagyobb összegzô munkák szerzối közül Osborne és társai (1994, 2004) a New Public Management irányzatának késői képviselóiként a gazdaság felől közelítik meg a modernizációt. Wimmer és társai (2007) a politika, a stratégiák és a társadalom hatásait is vizsgálják, az e-közigazgatásra hatást kifejtó tudományterületek körvonalazásával. Z. Karvalics (2008) döntően a feladatkör történetiségével és tartalmának változásaival foglalkozik. Az összefoglaló tudományos szintézis azonban mindmáig hiányzott.

\section{A közigazgatás új megközelítése, gondolati térképe}

A tudományterület alapjainak lerakása elốtti gondolkodás alatt, a lehetséges tényezók számbavételekor ha teljességre törekszünk -, felmerül a kérdés, hogy miért éppen a kiválasztott kérdések a legfontosabbak az e-közigazgatásban. Önkényes-e összeállításunk tematikája? Mit veszünk figyelembe és mit nem? Vajon csakugyan azok-e a legfontosabb pillérek, amelyekról beszélünk, és ha igen, miért?

A válaszokat több oldalról kaphatjuk meg. A legegyszerúbb - bár önigazoló - válasz az, hogy a modern közigazgatás-tudomány által érintett területeket integrálva nem nyúlhatunk mellé. A másik - relevánsabbnak tûnố - választ azoknak a tudományos diskurzusoknak (lásd korábban) az áttekintése adja meg, amelyek az elektronikus közigazgatás valamelyik aspektusával foglalkoznak, annak sikertényezóit vizsgálják. A harmadik, az e-közigazgatáshoz kapcsolódó jogi és egyéb dokumentumanyag (stratégiák, határozatok, törvények, rendeletek stb.) áttekintéséből adódik, a fóbb csomópontok kiemelésével. E három halmaz közös metszetét vesszük vizsgálódásunk alapjául.

Az információs társadalom kiépítése jegyében kidolgozott e-közigazgatási stratégiák majd két évtizede az alábbi négy fố témáról szólnak, eltérô hangsúlyokkal, és elvárásokat fogalmaznak meg ezekre vonatkozóan:

- infrastruktúra,

- szabályozás és intézményrendszer,

- tartalom,

- felhasználók.

Ezekhez illeszkedik a $\mathrm{K}+\mathrm{F}$ kérdésköre, amely horizontálisan érinti a rendszer valamennyi említett összetevőjét. Ha a fentiekhez hozzátesszük még a tudományos diskurzusok témáit (pl. az e-világban érvényesüló közigazgatás-technológiai módszereket), a társadalmi alapozást, az új államelméleteket (pl. a „,szolgáltató állam” elméleteit), az elméleti e-közigazgatási koncepciókat, és akár a rokon területek (pl. az e-gazdaság) releváns eredményeit is, többé-kevésbé teljes képet kaphatunk az e-közigazgatás egész területéról.

A 2. ábrán jól látszik, hogy az elôttünk álló főbb kérdéseket horizontálisan két csoportba oszthatjuk. $\mathrm{Az}$ e-közigazgatás elméletének általános része a makrokörnyezettel (a tudományterület pozicionálásával, az e-közigazgatási koncepciókkal, a szolgáltató állammal és az információs társadalmi kényszerekkel) foglalkozik, míg különös részének tárgyát a 


\section{Az e-közigazgatás új megközelítése, gondolati térképe}

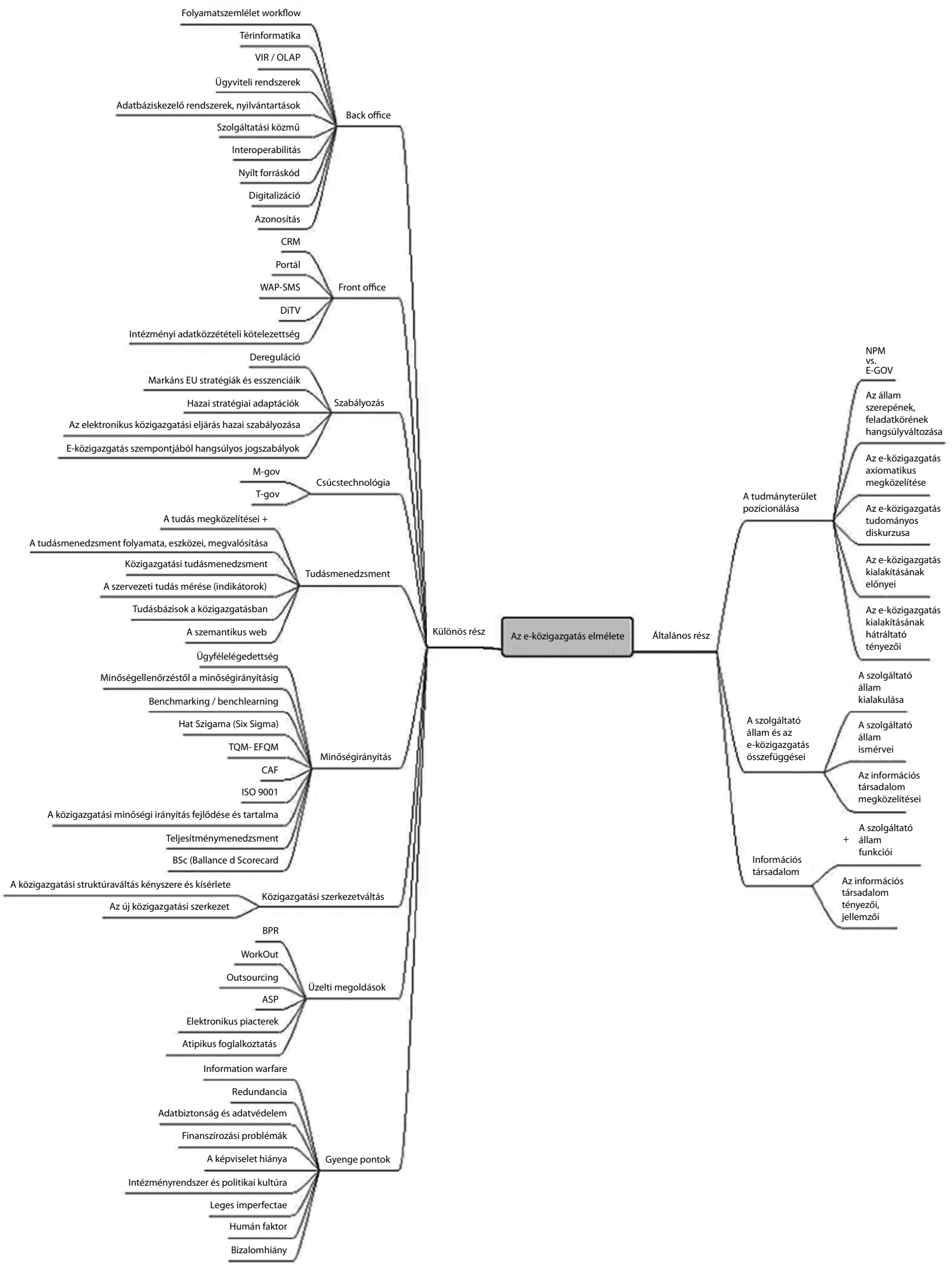


mikrokörnyezet, az e-közigazgatás eszközrendszere (a front office és back-office folyamatok), a szabályozás, a csúcstechnológia alkalmazása, a tudásmenedzsment, a minőségirányítás, az adaptálandó üzleti megoldások és a támadható, gyenge pontok alkotják.

\section{Paradigmadiffúzió}

A tárgyalási univerzum rögzítése és a tudományos kapaszkodók rendszerének megalkotása után csak egy tudományos feladat maradt (a gyakorlati alkalmazás nemes kihívása előtt), az új eszmék, módszerek találkozását kellett vizsgálni a régiekkel. Pragmatikusan: hogyan szivárognak be az új eszmék és módszerek a közigazgatásba, hogyan lesz e-közigazgatás? Sőt, ha igaznak fogadjuk el azt az állítást, amely az e-közigazgatásról mint tudományterületról beszél, hogyan tudjuk elhatárolni a közigazgatás-tudomány hagyományos tárgyától, mikor mindkét fajta vizsgálódás gyakorlati terepe napjaink múködő közigazgatása?

Paradigmaváltásról beszélhetünk? Esetleg az eszmék egyfajta rétegeződéséról? ${ }^{5}$ Vagy valami másról van szó? Ezt az ismeretelméleti kérdést egy új fogalom bevezetésével válaszolhatjuk meg.

Paradigmaváltásra akkor kerülhet sor, amikor egymás mellett van jelen egy centrális eszme (a hagyományos közigazgatási felfogás, a maga off-line meghatározottságával és módszereivel, amely az elektronikus szolgáltatásokat szükséges rossznak, és kizárólag eszköznek tekinti) és több, egyelőre perifériális eszme (esetünkben az e-közigazgatás, vagy akár a New Public Management). Az eszmék posszibilitásuk és plauzibilitásuk függvényében változtatják pozícióikat: az NPM vagy az e-közigazgatás egyre inkább centrális helyzetbe kerül, és végül az egyik nyer. Ez a modell feltételezi, hogy az eszmék minimális kölcsönhatásban vannak egymással, az új centrális eszme nem fertőződik a régiekkel, vagyis az új centrális eszme szakít a régivel és „új világot” teremt. Ez volna maga a paradigmaváltás. A mi problémánk esetében azonban nem erról van szó. Az e-közigazgatás a hagyományos közigazgatás-tudomány alapjain nyugszik, annak törvényszerúségeire épít, sok esetben visszanyúl hozzá, eredményeit felhasználja és kombinálja. (A kölcsönhatások erôteljesen érezhetők.)

Ha az eszmék ,földtani rétegződésérôl” beszélünk, ismét elégtelen képet kapunk. A rétegeződés azt jelentené, hogy a két nem közvetlenül érintkező réteg már nincs egymásra hatással. Az egyes rétegek egyben zárórétegként is múködnének, azaz például a $N e w$ Public Management sok területen elzárná az érintke- zést a hagyományos szemlélet és az e-közigazgatás között. (Ezzel szemben tudjuk, hogy nem ez a helyzet. Az e-közigazgatás elméletei számos esetben a New Public Management előtti idókhöz térnek vissza, cáfolva az NPM teoretikusainak több elgondolását.)

Az e-közigazgatás helyzetére a paradigmadiffúzió elmélete adhat plasztikus magyarázatot. Ez a megközelítés elveti a szigorú határokat, inkább vonzásközpontokkal számol. Ott, ahol a vonzáskörzetek határai nem élesek, inkább centrális eszmei vonzáskörzetekról beszélhetünk, mintsem centrális eszmékrôl. A diffúzió jelenségének leírására a természettudományokban használatos szókinccsel élve azt mondhatjuk, hogy az eszméket szemipermeábilis hártyák választják el egymástól, amelyek egyes elemeket átengednek, és az egyik rendszerből a másikba átjutott elemek megváltoztatják (megfertőzik) az ott meglévő eszmeállományt. Minden elem minden másikkal érintkezik, minden mindenre hatással van. Ebben a rendszerben ritkán túnik el bármelyik elem, az összetevoók inkább megváltoznak, néha előnyükre (best practices), néha hátrányukra (worst practices). A szinergia révén az eszmék ,integrálja” (a gondolati függvény görbéje alatti terület: az új tudásvagyon) nagyobb lesz, mint az összeadandók együttes értéke.

Az eszmék találkozásainak eredményeként a perifériális eszmék átalakulnak és centrális helyzetbe kerülhetnek, míg a korábbi centrális eszme perifériális jellegúvé válik. Közben az eszmék kölcsönhatása, folyamatos idomulása figyelhetô meg. Az egymáshoz közelítő eszmék végül egyesülnek. Azok az eszmék, amelyeknek a határfelületei nem eléggé átjárhatóak, elóbb-utóbb elsorvadnak és teljesen perifériális helyzetbe jutnak, majd a feledés homályába merülnek.

A közigazgatás jelenleg e diffúziós folyamatok hatásai alatt változik. Az e-közigazgatás így lesz egy tudományos ismerethalmaz, amely többé vagy kevésbé átalakítja a közigazgatást. A közigazgatás hossz távon tehát közigazgatás marad (,e” jelzőcske nélkül), magába foglalva mindazon dolgokat, amiket ma „e-közigazgatásnak” hívunk. Előnyére-e, vagy inkább a hátrányára? A válasz függ attól, hogy az átalakulás szerves lesz-e, hogy a rendelkezésre álló eszköztárból mit és hogyan használ fel, és hogy a társadalmi bizalom, a gazdasági helyzet és a politikai kultúra alakulása kedvezô vagy kedvezôtlen környezetet biztosít-e fejlődéséhez.

A függő feltételektôl függetlenül az állampolgárok „csak” közigazgatást fognak látni a továbbiakban is, azonban egy tudományos igényư ismerethalmaz tükrében könnyebben tudják majd megítélni, hogy a „van” mennyiben különbözik a ,lehetne” és a ,kellene lennie” kategóriáktól. A ,lesz”, amelyre vonatkozó elkép- 
zelések választási időszakban erôsebbek, és nagyobb nyilvánosságot is kapnak, nem vehetők komolyan a valódi tudományos szférában, csupán „tudományos szépirodalmak", amelyeket politikai ambíciókkal felvértezett hajóskapitányok és önjelölt matrózok kiabálnak, elnyomva a realitás szkülláinak és kharübdiszeinek vészjósló hangjait.

\section{Lábjegyzet}

${ }^{1}$ E-közigazgatási szakirány akkreditálása azonban folyamatban van.

${ }^{2}$ www.nsf.gov

${ }^{3}$ TCO: Total Costs of Ownership, a tulajdonlás teljes költsége. Nem elég például egy szoftvert megvásárolni vagy kidolgoztatni, az üzemeltetés során egyéb (többek között karbantartási, felügyeleti, szerviz, helpdesk stb.). költségek is felmerülnek. A költségvetés tervezésekor ezekkel is számolni kell, ezt azonban sok esetben elfelejtik.

${ }^{4}$ A New Public Management és az e-közigazgatás célés fogalomrendszere korántsem azonos, kölcsönhatásuk azonban vitathatatlan.

${ }^{5}$ Lásd Ingraham, P. - K. Joyce, P. K. - Donahue, A. K.: Government Performance: Why Management Matters. Baltimore: John Hopkins University Press

\section{Felhasznált irodalom}

Budai B. B. (2009): Az e-közigazgatás elmélete, Akadémiai Kiadó, Budapest
Bogóné dr. Jehoda R. (2006): Az OECD véleménye a magyar e-kormányzatról. Jegyzô és Közigazgatás, VIII./6.

Codagnone, C. - Wimmer, M.A. (szerk.) (2007): Roadmapping eGovernment Research - Visions and Measures towards Innovative Governments in 2020. eGovRTD2020 Project Consortium

Horváth M. T. (szerk.) (1998): Közigazgatás - szorítóban: Átalakulási tanulmányok a századvégen, Unió Kiadó, Budapest

IFUA Horváth \& Partners (2004): A közigazgatási reform megvalósítása Magyarországon (tanulmány); IFUA, Budapest

Ingraham, P. - Joyce, P.K. - Donahue, A.K.: Government Performance: Why Management Matters. John Hopkins University Press, Baltimore

Jenei Gy. (2005): Közigazgatás-menedzsment. Századvég, Budapest

Kis - Hutkai - Tóth - Dobos (2008): Zárótanulmány A felsőfokú közigazgatási szakemberképzés szerkezeti és tartalmi megújítása. Budapesti Corvinus Egyetem, Budapest

Lórincz L. (2005): A hatékony állam. Magyar Közigazgatás, 2005/8.

Osborne, D. - Hutchinson, P. (2004): The Price of Government: Getting the Results We Need in an Age of Permanent Fiscal Crisis. Basic Books

Osborne, D. - Gaebler, T. (1994): Új utak a közigazgatásban. Vállalkozói szellem a közösségi szektorban. Kossuth Kiadó, Budapest

Synergy - The IDABC Quarterly - ISSUE 10. (2008): IDABC and Beyond, avoiding digital barriers

Z. Karvalics L. (2008): Úton a digitális kori kormányzás felé, Demos Magyarország, Budapest 